"Mircea cel Batran" Naval Academy Scientific Bulletin, Volume XIX - 2016 - Issue 1

Published by "Mircea cel Batran" Naval Academy Press, Constanta, Romania /I The journal is indexed in:

PROQUEST / DOAJ / DRJI / JOURNAL INDEX / I2OR / SCIENCE LIBRARY INDEX / Google Scholar / Crossref /

Academic Keys / ROAD Open Access / OAJI / Academic Resources / Scientific Indexing Services / SCIPIO

\title{
POLLUTANT EMISSION NUMERICAL ANALYSIS OF A MARINE ENGINE
}

\author{
Dorel Dumitru VELCEA ${ }^{1}$ \\ ${ }^{1}$ PhD Student, Military Technical Academy, Bucharest
}

\begin{abstract}
The energies produced by the diesel engines of strong power are largely used in marine propulsion because of their favorable reliability and their significant output. However, the increasingly constraining legislations, aimed at limiting the pollutant emissions from the exhaust gas produced by these engines, tend to call into question their supremacy. The analysis of the pollutant emissions and their reduction in the exhaust gas of the slow turbocharged marine diesel engine using ANSYS 15 constitutes the principal objective of this study. To address problems of global air pollution due to the pollutant emission from fuel oil engine combustion, it is necessary to understand the mechanisms by which pollutants are produced in combustion processes. In the present work, an experimental and numerical study is carried out on a unit of real use aboard a car ferry ship. A numerical model based on a detailed chemical kinetics scheme is used to calculate the emissions of NOx, SOx and Sooth in an internal combustion engine model for the same characteristics of the real unit. The combustion process parameters based on the numerical model might now be optimized in order to decrease the pollutant emissions in order to meet the IMO regulations.
\end{abstract}

Keywords: Combustion Simulation; Marine Engines; Finite Volume Analysis, Pollutant Emissions

\section{Introduction}

In this paper we'll investigate the pollutants emission following the combustion stage taking place between BDC and TDC for an engine type MAN B\&W 6S60MC-C as seen in the figure below:

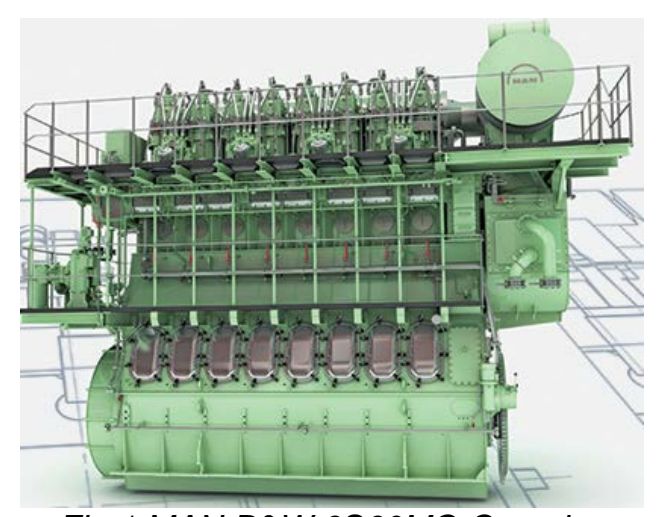

Fig.1 MAN B\&W 6S60MC-C engine

The software to be used is ANSYS 15.

The energies produced by the diesel engines of strong power are largely used in marine propulsion because of their favorable reliability and their significant output. However, the increasingly constraining legislations, aimed at limiting the pollutant emissions from the exhaust gas produced by these engines, tend to call into question their supremacy.

Most bibliographical studies on the various approaches to estimate the rate of emissions cover many established models such as:

(i) the direct models that lead to digital resolution of Navier Stokes, energy conservation, and phenomenological species equations that have given rise to codes: CONCHAS, KIVA, and KIVA II,

(ii) the phenomenological models that simulate combustion, using formulations based on different physical and chemical phenomena that were experimentally observed and described, (iii) the empirical models establishing kinetics patterns reduced to a dozen variables necessary for calculations of turbulent flames equations which lead to calculate the formation of pollutants.

Many other studies were undertaken, on the experimental level as well as on the analytical level, in order to study the mechanisms which govern the formation of the various produced pollutants. The study of combustion chemistry enjoys an undeniable anticipation, and has now acquired a certain maturity.

The analysis of the pollutant emissions and their reduction in the exhaust gas of the slow turbocharged marine diesel engine using ANSYS 15 , constitutes the principal objective of this study.

\section{CAD and Finite Volume Analisys (FVA) Model of the IC}

The goal of this paper is to simulate the pollutants emission of the combustion stage for MAN B\&W 6 S60MC-C engine. Therefore the CFD will have as fluid domain the "negative-half" of the InCylinder (the combustion chamber along with its ports) as given below (CAD): 
"Mircea cel Batran" Naval Academy Scientific Bulletin, Volume XIX - 2016 - Issue 1

Published by "Mircea cel Batran" Naval Academy Press, Constanta, Romania /I The journal is indexed in: PROQUEST / DOAJ / DRJI / JOURNAL INDEX / I2OR / SCIENCE LIBRARY INDEX / Google Scholar / Crossref / Academic Keys I ROAD Open Access / OAJI / Academic Resources / Scientific Indexing Services / SCIPIO

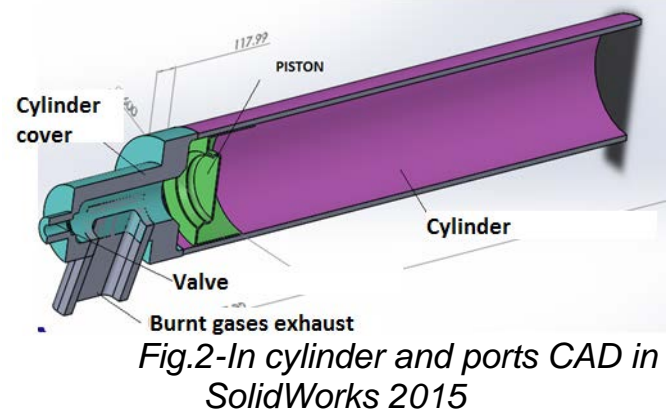

Once the cylinder CAD is generated in SolidWorks 2015, the CAD model is imported in ANSYS Modeler module and the "negative" of the geometry is obtained as shown below:

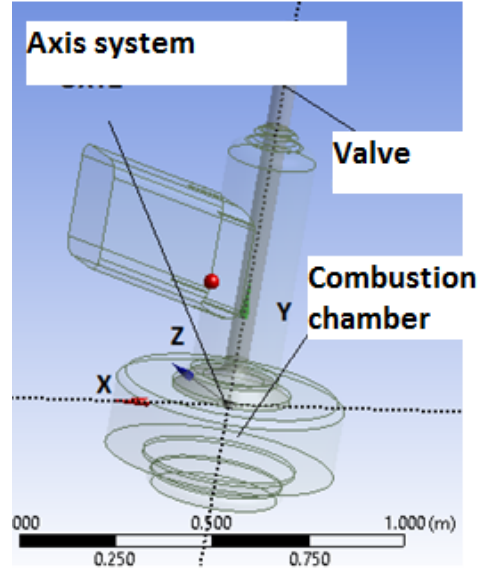

Fig.3 The ports and the combustion chamber

Furthermore, using the ICE module of ANSYS software a $90^{\circ}$ sector of the combustion chamber is modeled as given below, and is populated with finite volume elements:

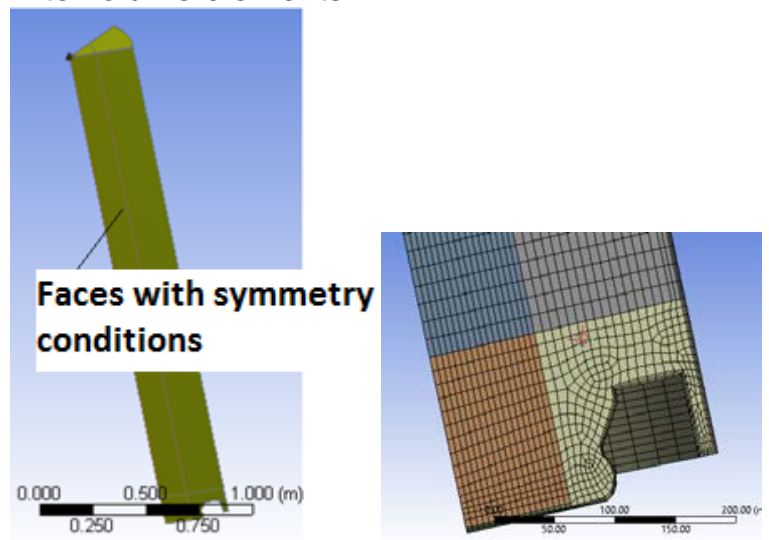

Fig.4 ICE modeled sector of the combustion chamber

The resulting model is imported in Fluent 15 module of ANSYS for further processing. The input data are as given below:

\begin{tabular}{|c|c|c|c|c|}
\hline $\begin{array}{c}\text { Connecting } \\
\text { rod length } \\
{[\mathrm{mm}]}\end{array}$ & $\begin{array}{c}\text { Crank } \\
\text { length } \\
{[\mathrm{mm}]}\end{array}$ & $\begin{array}{l}\text { Engine } \\
\text { [RPM] }\end{array}$ & $\begin{array}{c}\text { Exhaust } \\
\text { valve } \\
\text { opening } \\
\text { angle } \\
\text { [CAD] }\end{array}$ & $\begin{array}{c}\text { Closing } \\
\text { angle for the } \\
\text { scavenging } \\
\text { ports [CAD] }\end{array}$ \\
\hline 3000 & 1200 & 100 & 480 & 210 \\
\hline $\begin{array}{c}\text { Temperature } \\
\text { of the } \\
\text { combustion } \\
\text { chamber }\left[{ }^{0}\right. \\
\mathrm{K}]\end{array}$ & $\begin{array}{c}\mathrm{O}_{2} \\
\text { mass } \\
\text { fraction } \\
\text { in the } \\
\text { air } \\
\end{array}$ & $\begin{array}{c}\mathrm{CO}_{2} \\
\text { mass } \\
\text { fraction } \\
\text { in the } \\
\text { air } \\
\end{array}$ & $\begin{array}{c}\mathrm{H}_{2} \mathrm{O} \\
\text { mass } \\
\text { fraction } \\
\text { in the } \\
\text { air } \\
\end{array}$ & $\begin{array}{c}\text { Pressure at } \\
\text { the } \\
\text { compression } \\
\text { starting [Pa] }\end{array}$ \\
\hline 400 & 0,232 & 0,00046 & $5 e-7$ & $2.3 e 5$ \\
\hline
\end{tabular}

\begin{tabular}{|c|}
\hline Fuel \\
\hline \hline Diesel \\
\hline \hline Temperature \\
at the \\
beginning of \\
the \\
compression \\
{$\left[{ }^{0} \mathrm{~K}\right]$} \\
\hline 302 \\
\hline \hline Cylinder \\
diameter \\
{$[\mathrm{mm}]$} \\
\hline 600 \\
\hline
\end{tabular}

Table 1 Model input data

The fuel injection process is very important in terms of combustion. The model of injections comprise four injectors positioned half radius inside the combustion chamber, each injector having four nozzles as seen in the figure below:

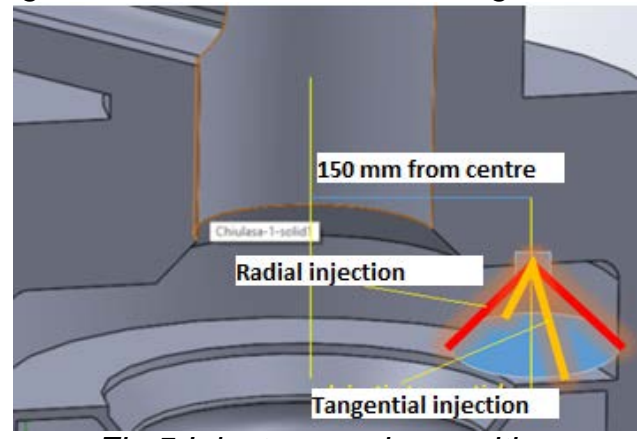

Fig.5 Injector nozzles position

The main parameters of the injection process are as follows:

- Fuel-Diesel

- Injection CA start angle-350

- Injection CA stop angle-370

- Fuel temperature-366.7 deg K

- Angle of the nozzle in report to the cylinder axis-70 deg

- Position of the injector axis in report to the cylinder axis-150 mm

- Fuel velocity at the exit from nozzle-500 $\mathrm{m} / \mathrm{sec}$ 
"Mircea cel Batran" Naval Academy Scientific Bulletin, Volume XIX - 2016 - Issue 1

Published by "Mircea cel Batran" Naval Academy Press, Constanta, Romania /I The journal is indexed in: PROQUEST / DOAJ / DRJI / JOURNAL INDEX / I2OR / SCIENCE LIBRARY INDEX / Google Scholar / Crossref /

Academic Keys / ROAD Open Access / OAJI / Academic Resources / Scientific Indexing Services / SCIPIO

- The fuel cone angle at the exit from nozzle-9 deg

- The fuel cone radius at the exit from nozzle-0,127 mm

- Fuel mass flux-1 kg/sec

- Jet breaking model- KHRT standard

- $\quad$ The drag law of the fuel jet-Dynamic drag

- Tracking stochastic of fuel dropletsDiscrete Random Walk Model and Random Eddy Lifetime

- NOx computed emission-Thermal NOx, Prompt NOx, Intermediate NOx

- Sulphur mass fraction inside the fuel=8.6e-6

- $\quad$ Sooth model=One step standard

\section{CFD Simulation Results}

The combustion is starting at $360 \mathrm{deg}$. CA and ends at 530 deg CA when the scavenging process starts.

The results analysis will cover the following crank angles (CA):

- $\quad \mathrm{CA}=375$ (deg) in which the injection process ended since 5 deg CA

- $\mathrm{CA}=420(\mathrm{deg})$ in which the injection process ended since 50 deg $C A$

- $\mathrm{CA}=450$ (deg) in which the injection process ended since 80 deg CA

- $\quad \mathrm{CA}=480$ (deg)-end of combustion

\section{Results for CA = 375 (deg)}

\section{- Fuel mass fraction}

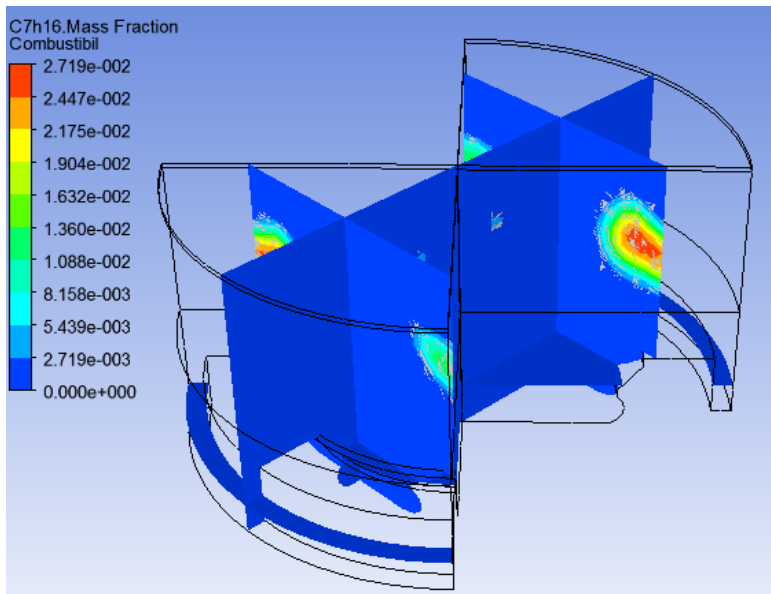

Fig. 6 Fuel mass fraction fields for $C A=375 \mathrm{deg}$ Even though the combustion process started since 16 deg CA, the injected fuel is accumulating near the injection nozzles reaching a maximum of 0.0271 .

\section{- NOx mass fraction}

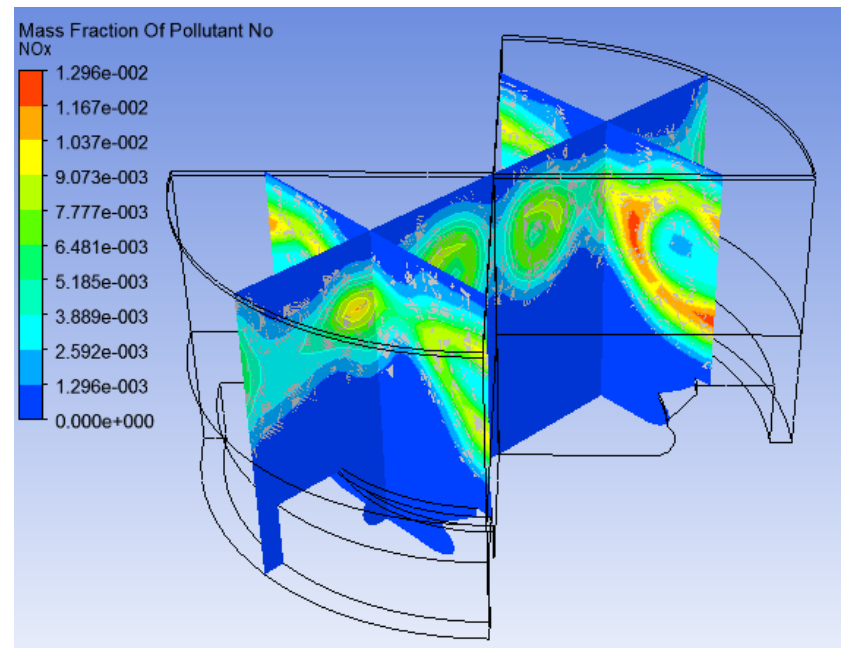

Fig.7-NOx mass fraction fields for $C A=375 \mathrm{deg}$

The temperatures developed inside the combustion chamber are suitable for NOx formation so that near the injection nozzles there are peak valued of the NOx mass fraction of 1.29e-2.

\section{- SOx mass fraction}

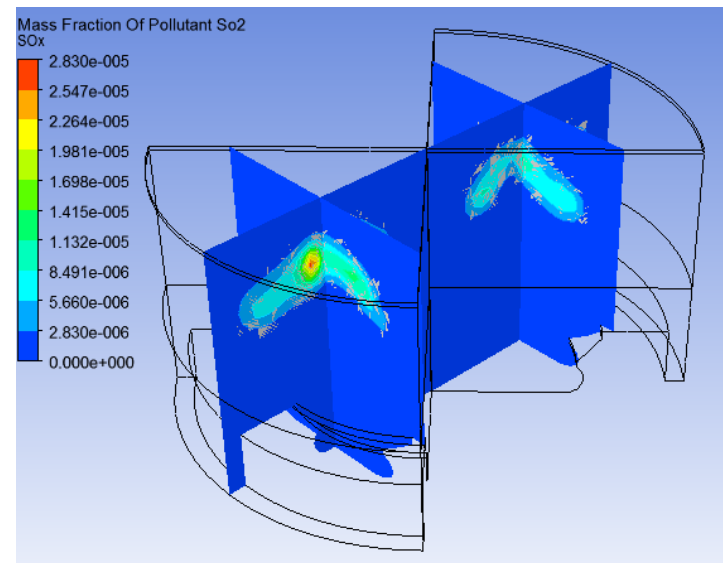

Fig.8-SOx mass fraction fields for $C A=375 \mathrm{deg}$

The formation of SOx is in full swing at this time, in the same vicinity to the injection nozzles where the mass fraction is reaching a peak value of 2.83e-5. 
"Mircea cel Batran" Naval Academy Scientific Bulletin, Volume XIX - 2016 - Issue 1

Published by "Mircea cel Batran" Naval Academy Press, Constanta, Romania /I The journal is indexed in: PROQUEST / DOAJ / DRJI / JOURNAL INDEX / I2OR / SCIENCE LIBRARY INDEX / Google Scholar / Crossref I Academic Keys / ROAD Open Access / OAJI / Academic Resources / Scientific Indexing Services / SCIPIO

\section{- Sooth mass fraction}

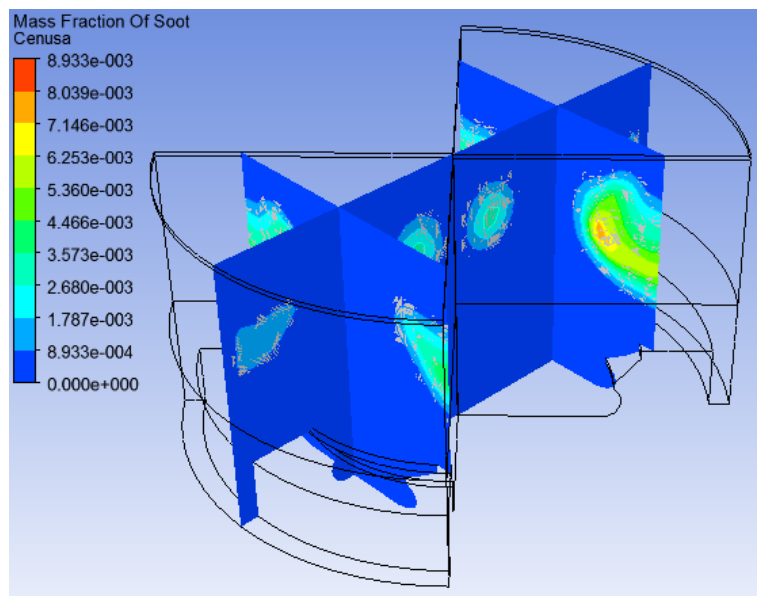

Fig.9-Sooth mass fraction fields for $C A=375 \mathrm{deg}$

The sooth formation zone near the nozzles tips is expanding having a maximum of $8.93 e-3$.

\section{Results for $C A=420$ (deg)}

\section{- Fuel mass fraction}

The fuel reserve due to the combustion process is diminishing to a maximum of $1.998 \mathrm{e}-11$ mass fraction, tending to migrate near the lateral upper zone of the combustion chamber as seen above.

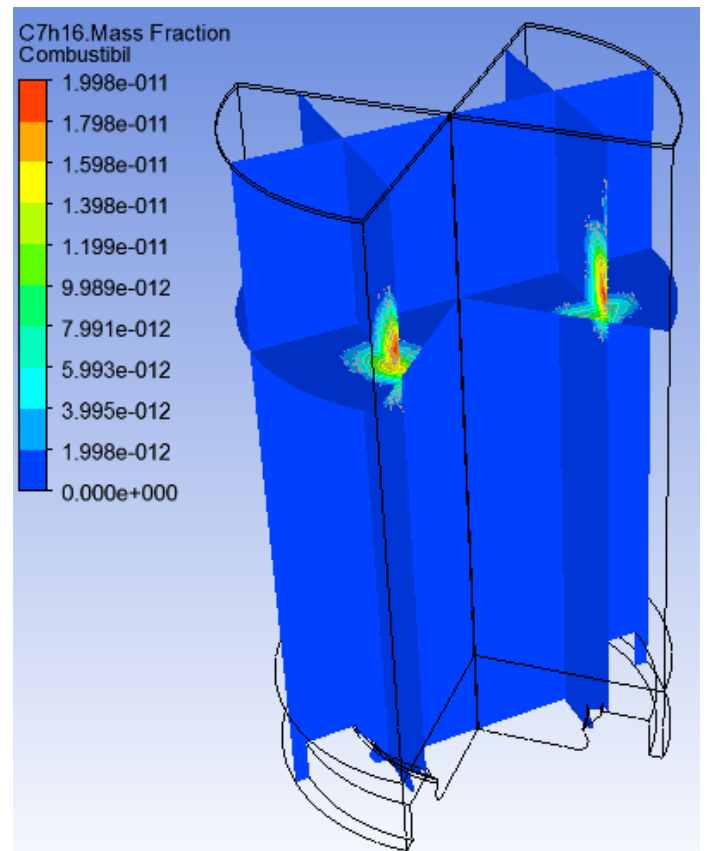

Fig.10 Fuel mass fraction fields for $C A=420 \mathrm{deg}$

DOI: 10.21279/1454-864X-16-I1-054

\section{- NOx mass fraction}

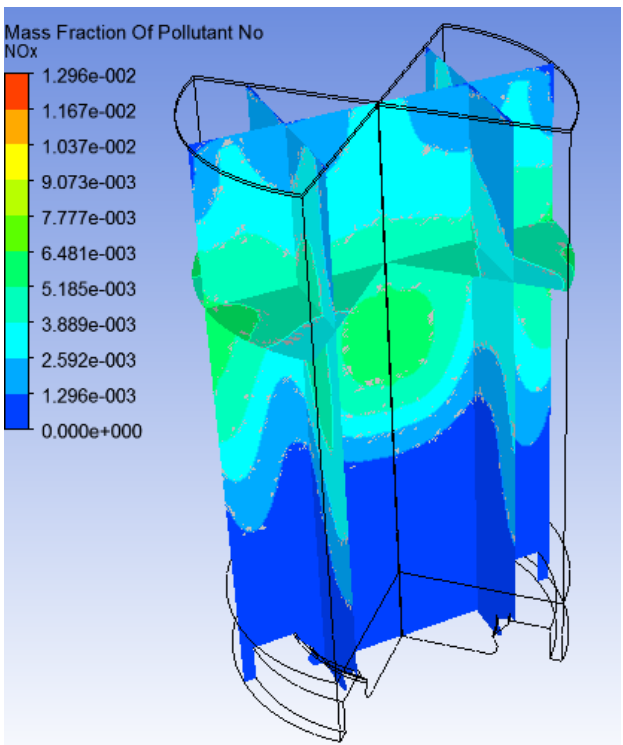

Fig.11-NOx mass fraction fields for $C A=420 \mathrm{deg}$

The formation conditions for NOx remains good so that the pollutant occupied zone is extending inside the central zone of the combustion chamber, having a maximum of $1,296 \mathrm{e}-2$ mass fraction, decreasing from the previous reading due to increasing volume of the chamber.

\section{- SOx mass fraction}

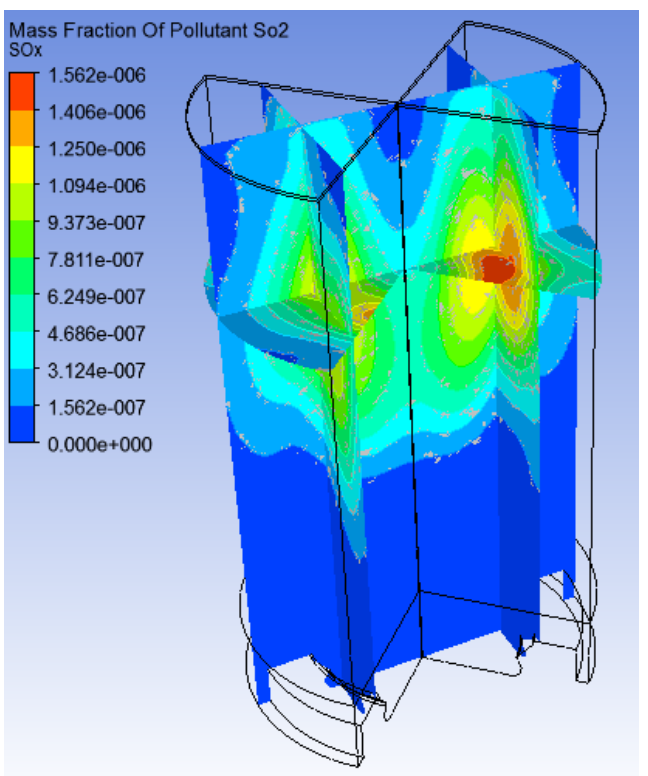

Fig.12-SOx mass fraction fields for $C A=420 \mathrm{deg}$

The zone occupied by SOx is moving downwards reaching a maximum of $1,562 \mathrm{e}-6$, relatively smaller than the one recorded for the previous reading, and that is because the increased volume of the combustion chamber. 
"Mircea cel Batran" Naval Academy Scientific Bulletin, Volume XIX - 2016 - Issue 1

Published by "Mircea cel Batran" Naval Academy Press, Constanta, Romania /I The journal is indexed in: PROQUEST / DOAJ / DRJI / JOURNAL INDEX / I2OR / SCIENCE LIBRARY INDEX / Google Scholar / Crossref / Academic Keys / ROAD Open Access / OAJI / Academic Resources / Scientific Indexing Services / SCIPIO

\section{- Sooth mass fraction}

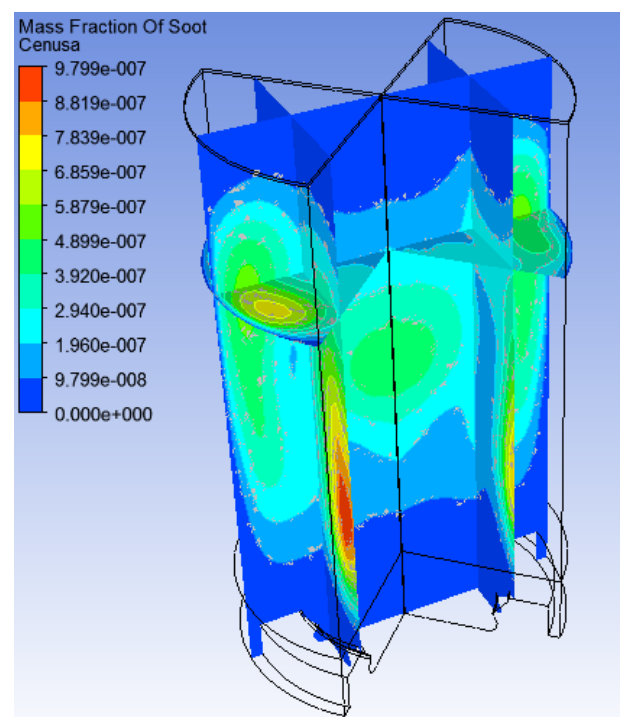

Fig.13-Sooth mass fraction fields for $C A=420 \mathrm{deg}$

The mass fraction of sooth reaches a peak value of $9,799 \mathrm{e}-7$ in the upper central zone of the combustion chamber.

\section{Results for $C A=450$ (deg)}

\section{- Fuel mass fraction}

The fuel reserve due to the combustion process is almost exhausted only a small region inside the upper central part of the chamber has a peak value of mass fraction of 1,087e-12.

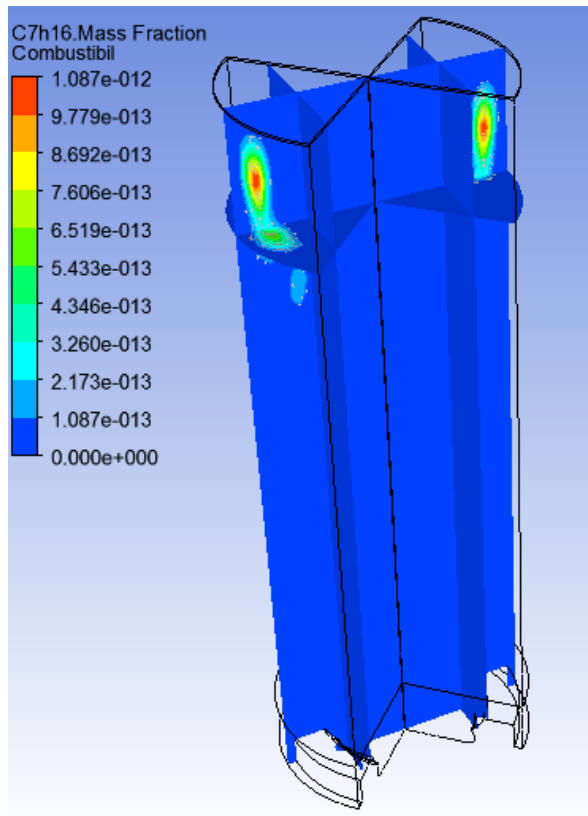

Fig.14 Fuel mass fraction fields for $C A=450 \mathrm{deg}$
- NOx mass fraction

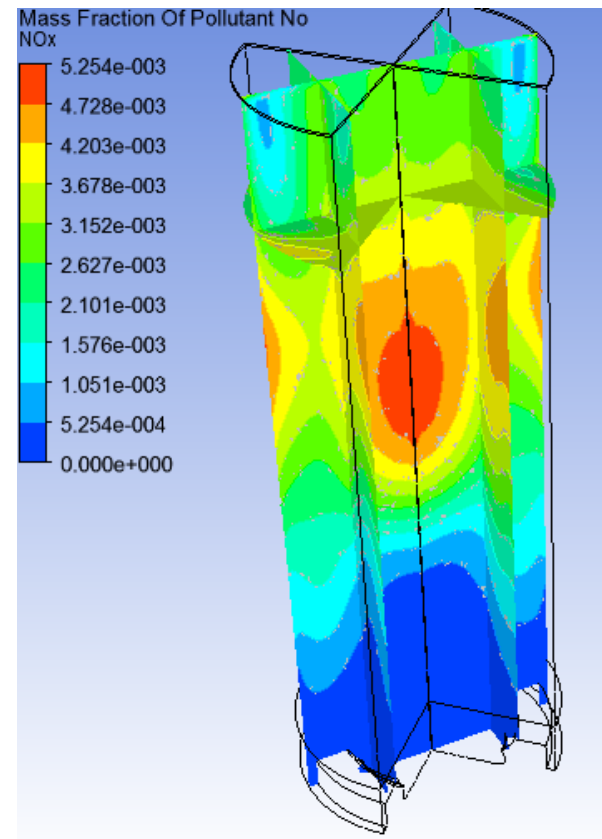

Fig.15-NOx mass fraction fields for $C A=450 \mathrm{deg}$ The formation conditions for NOx now are becoming worse since the temperatures inside the cylinder dropped, the peak values being reduced to a value of $5,254 \mathrm{e}-3$ mass fraction as seen above.

\section{- SOx mass fraction}

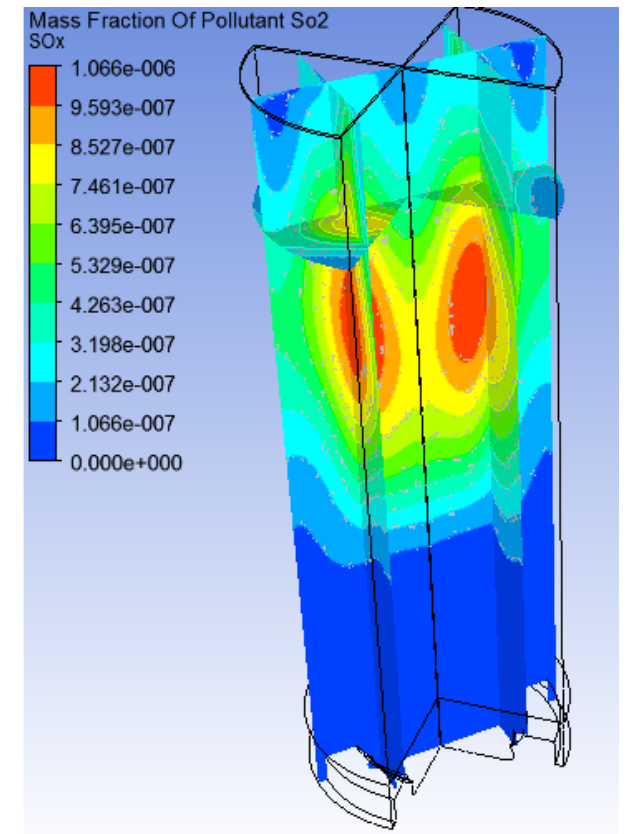

Fig.16-SOx mass fraction fields for $C A=450 \mathrm{deg}$ 
"Mircea cel Batran" Naval Academy Scientific Bulletin, Volume XIX - 2016 - Issue 1

Published by "Mircea cel Batran" Naval Academy Press, Constanta, Romania /I The journal is indexed in: PROQUEST / DOAJ / DRJI / JOURNAL INDEX / I2OR / SCIENCE LIBRARY INDEX / Google Scholar / Crossref / Academic Keys / ROAD Open Access / OAJI / Academic Resources / Scientific Indexing Services / SCIPIO

The zone occupied by SOx is moving downwards due to the piston motion, the maximum value is now $1,066 \mathrm{e}-6$.

\section{- Sooth mass fraction}

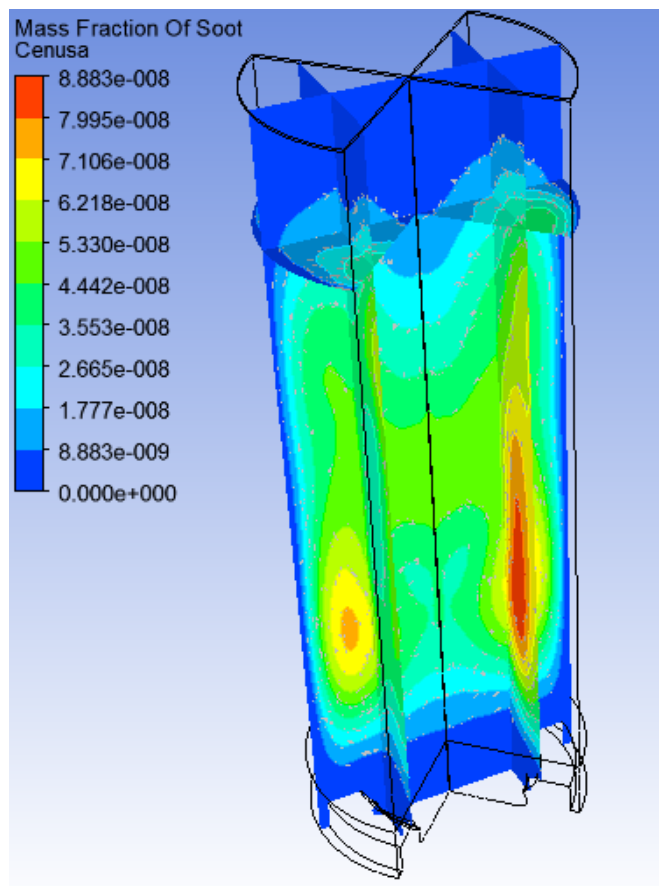

Fig.17-Sooth mass fraction fields for $C A=450 \mathrm{deg}$

The mass fraction of sooth reaches a peak value of $8,883 e-8$ in the upper central zone of the combustion chamber.

\section{Results for CA $=480$ (deg)-Combustion stage ending}

\section{- Fuel mass fraction}

The fuel reserve due to the combustion process is virtually exhausted indicating a thorough burning of the fuel during the combustion phase of the engine cycle.

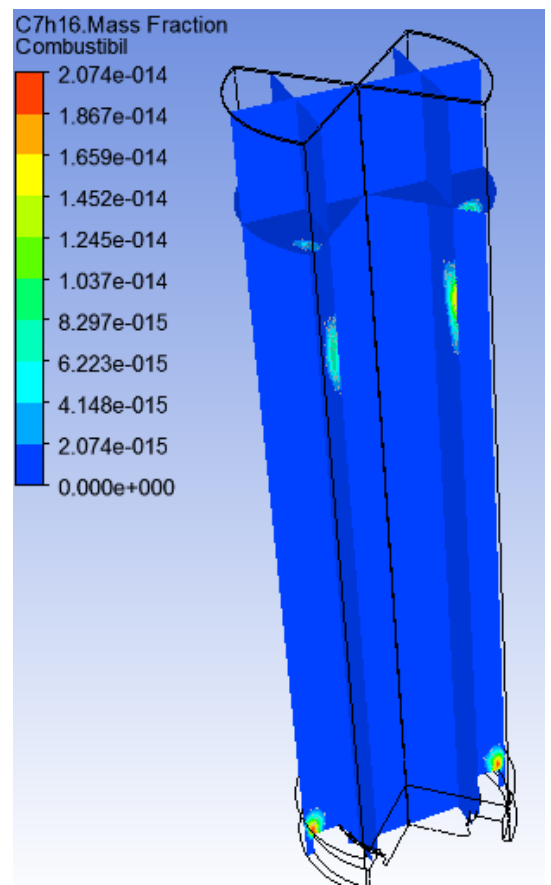

Fig.18 Fuel mass fraction fields for $C A=480 \mathrm{deg}$

- NOx mass fraction

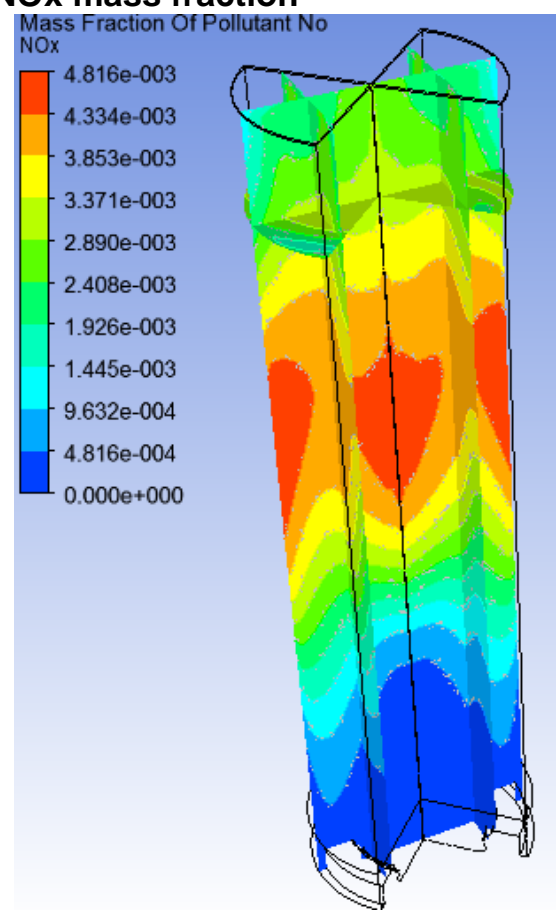

Fig.19-NOx mass fraction fields for $C A=480 \mathrm{deg}$ The formation conditions for NOx now are becoming worse since the temperatures inside the cylinder dropped, the peak values being reduced to a value of $4,816 \mathrm{e}-3$ mass fraction as seen above. 
"Mircea cel Batran" Naval Academy Scientific Bulletin, Volume XIX - 2016 - Issue 1 Published by "Mircea cel Batran" Naval Academy Press, Constanta, Romania /I The journal is indexed in: PROQUEST / DOAJ / DRJI / JOURNAL INDEX / I2OR / SCIENCE LIBRARY INDEX / Google Scholar / Crossref / Academic Keys / ROAD Open Access / OAJI / Academic Resources / Scientific Indexing Services / SCIPIO

\section{- SOx mass fraction}

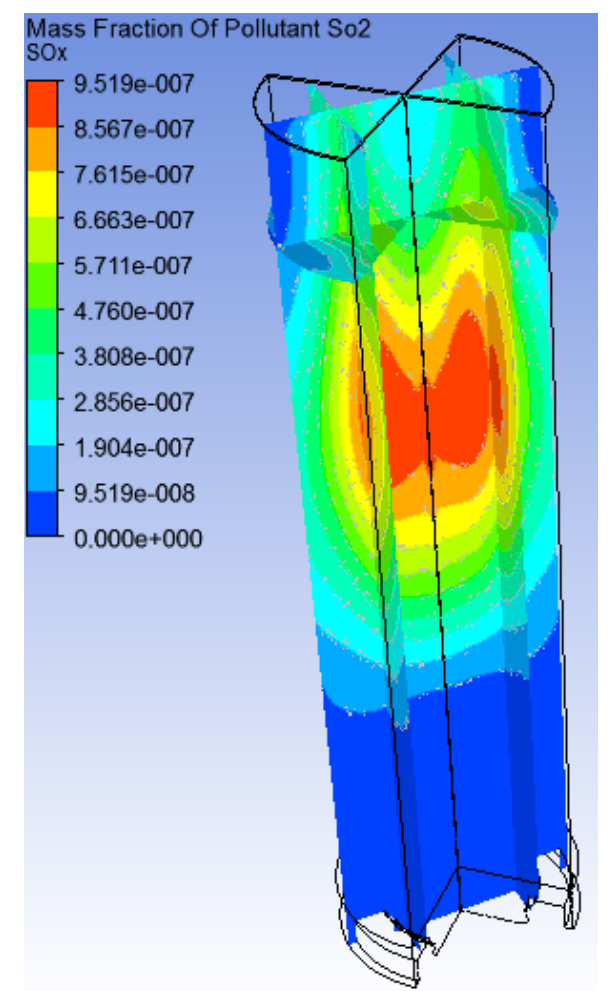

Fig.20-SOx mass fraction fields for CA=480 deg The zone occupied by SOx is moving downwards due to the piston motion, the maximum value is now 9,519e-7.

\section{- Sooth mass fraction}

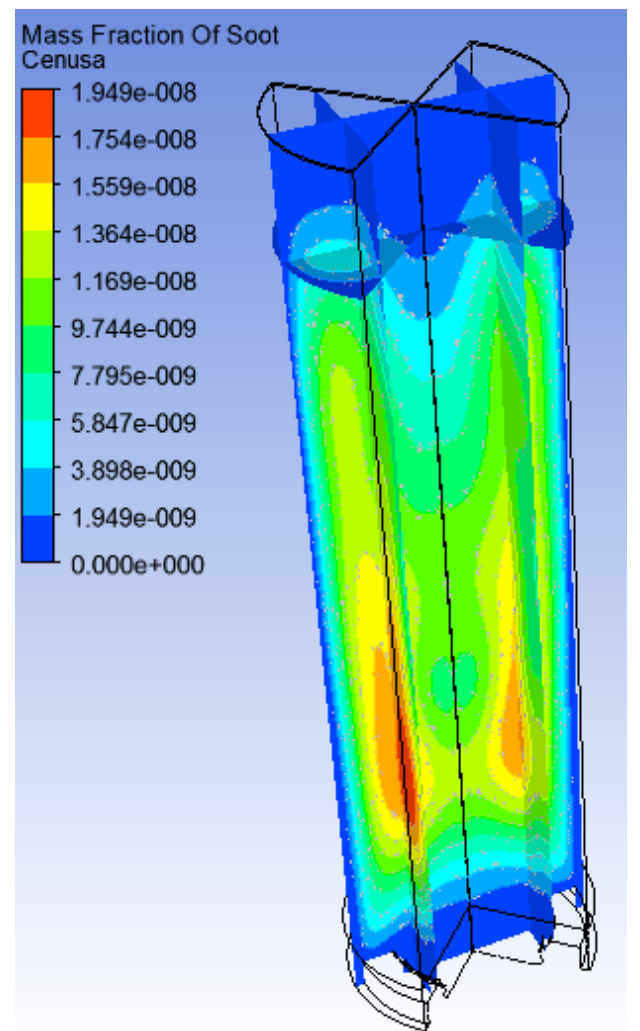

Fig.21-Sooth mass fraction fields for $C A=480 \mathrm{deg}$

The mass fraction of sooth reaches a peak value of la 1,949e-6 in the upper central zone of the combustion chamber.

\section{CONCLUSIONS}

To address problems of global air pollution due to the pollutant emission from fuel oil engine combustion, it is necessary to understand the mechanisms by which pollutants are produced in combustion processes. In the present work, an experimental and numerical study is carried out on a unit of real use aboard a car ferry ship. A numerical model based on a detailed chemical kinetics scheme is used to calculate the emissions of NOx, SOx and Sooth in an internal combustion engine model for the same characteristics of the real unit. The combustion process parameters based on the numerical model might now be optimized in order to decrease the pollutant emissions in order to meet the IMO regulations.

\section{BIBLIOGRAPHY}

[1] John B. Heywood. Internal Combustion Engine Fundamentals. McGraw-Hill, Inc, 1988.

[2] R.U.K. Gustafsson M. Bergman and B.I.R Jonsson. Scavenging system layout of a $25 \mathrm{cc}$ two-stroke engine intended for stratified scavenging. SAE paper no. 2002-32-1840, 2002.

[3] R.U.K. Gustafsson M. Bergman and B.I.R Jonsson. Emission and performance evaluation of a $25 \mathrm{cc}$ stratified scavenging two-stroke engine. SAE paper no. 2003-32-0047,

2003.

[4] Open CFD Limited. Open FOAM The Open Source CFD Toolbox Programmer's Guide Version 1.5, 2008.

[5] Open CFD Limited. OpenFOAM The Open Source CFD Toolbox User Guide Version 1.5, 2008.

[6] Masanori Noguchi Toshiharu Sawada, Minrou Wada and Buhei Kobayashi. Develope-ment of a low emission two-stroke cycle engine. SAE paper no. 980761, 1998.

[7] ANSYS 15.0 Help Library

[8] Sourabh Shrivastava, Padmesh Mandloi, Ajey Walavalkar-Modeling IC Engine Thermal Management using ANSYS CFD-ANSYS Inc. 